\title{
PANCASILA SEBAGAI NILAI DASAR PROFESI DOKTER
}

\author{
Hasrul Buamona \\ Kantor Hukum HB\&Partners \\ HB Institute Pusat Studi Hukum Kesehatan dan Kebijakan Publik \\ Email:asrul.rul36@yahoo.com
}

\begin{abstract}
Abstrak
Profesi dokter yang merupakan profesi tertua serta profesi mulia dengan tugas memberikan pelayanan medis kepada masyarakat, dihadapkan dengan permasalahan dokter yang tidak berkeinginan untuk mengabdi secara utuh kepada masyarakat tanpa membedakan latar belakang ekonomi dan sosial. Ini seolah betentangan dengan Pancasila sebagai nilai-nilai dasar Negara Indoensia. Tulisan ini mengkaitkan hubungan antara profesi dokter dengan nilai-nilai Pancasila sebagai nilai dasar negara Indonesia. Hasil kajian menunjukkan bahwa dokter dalam menjalankan profesi dokter belum menjiwai nilai Pancasila, dikarenakan masih banyak dokter yang ingin mencari keuntungan ekonomi dalam menjalankan profesi dokter, serta nilai Pancasila hanya dijadikan sebagai seremonial. Sepantasnya nilai Pancasila dimasukan dalam kurikulum akademik dokter agar supaya menjadi kredo dokter untuk memberikan pelayanan medis kepada pasien sepenuh hati.
\end{abstract}

Kata Kunci: Pancasila; Nilai Dasar; Profesi Dokter

\begin{abstract}
The medical profession which is the oldest profession and the noble one for he/she medical services to provide relief to the patient, is faced with the problem of doctors who make different between people economically and socially. Thus be in contradiction of 'Pancasila' (Indonesian Five Pillars) which is the essential core of Indonesia as a state. This paper connects between 'Pancasila' as a fundamental value of the Indonesian state and doctors as profession. The results showed that doctors in running the medical services are not animating the values of Pancasila, that is because there are still many doctors who only view his profession as economic benefit. The values of Pancasila are thought formally not practically. So it is urgent to enact the values of Pancasila into academic curriculum for he/she who become doctor will conduct the services full of conscience.
\end{abstract}

Key Words: Pancasila; Base of Values; Doctors

\section{A. PENDAHULUAN}

Profesi dokter merupakan salah satu profesi tertua di dunia selain profesi advokat. Profesi dokter juga disebut sebagai sebagai profesi mulia (nobile officium), hal ini dikarenakan hadirnya profesi dokter bertujuan untuk memberi kesembuhan bagi masyarakat yang sedang sakit dengan penuh hati nurani (Buamona, 2015: 3). 
Profesi dokter memiliki peran yang sangat penting dalam peradaban keilmuan dan teknologi. Salah satunya ilmuwan Islam Ibnu Sina yang merupakan bapak kedokteran dunia yang tidak hanya membangun pfondasi keilmuan profesi dokter dari hal teknis saja, namun juga sampai pada tatanan etika kedokteran dan sumpah kedokteran. Lebih dari itu, ia turut membangun filsafat kedokteran yang bersandarkan pada al Quran dan Sunah.

Kemajuan profesi dokter, baik dalam pendidikan sampai pada pelayanan medis terbaik dokter terhadap masyarakat (pasien), menjadi tolak ukur kemajuan suatu negara. Negara maju di dunia seperti Jepang dan Singapura begitu serius membangun sumber daya manusia melalui eksistensi dokter, termasuk pula membangun infrastruktur pelayanan medis. Karena bagi mereka pembangunan dalam ruang lingkup pelayanan kesehatan merupakan tolak ukur sebuah negara yang tidak hanya maju, namun juga menghargai hak kesehatan manusia sebagai Hak Asasi Manusia (HAM). Bagaimana dengan Indonesia, bukankah negara Indonesia juga menganut asas welfare state sebagaimana yang termuat dalam Alinea ke-4 Undang-Undang Dasar 1945 sebagai dasar hukum negara. Saat ini tidak banyak Sarjana Kedokteran yang ingin mengabdi di daerah terpencil di Indonesia. Minimnya fasilitas menjadi salah satu penyebab utama. Ada juga anggapan bahwa kuliah di bidang ini membutuhkan banyak biaya, sehingga bekerja di pedalaman dengan gaji minim, tentu tidak akan mengembalikan modal yang sudah dikeluarkan.

Pendidikan dokter yang terbilang mahal dibandingkan dengan pendidikan lainnya, memicu karakter dokter jauh dari nilai Pancasila. Dokter akan lebih berpikir menjalankan profesinya dengan tujuan hanya untuk mengejar keuntungan ekonomi semata dengan cara pragmatis, sehingga pengabdian kepada masyarakat yang tidak mampu secara ekonomi dan sosial tidak menjadi tujuan utama sebagaimana yang termuat dalam sumpah kedokteran.

Terkait dengan minimnya dokter yang mengabdi pada daerah terpencil di Indonesia, sehingga pernah dibahas dalam diskusi "Potensi dan Peran Institusi Pendidikan dalam Penyediaan Tenaga Kesehatan untuk Daerah Terpencil, Perbatasan dan Kepulauan (DTPK)" di Fakultas Kedokteran Universitas Gadjah Mada (UGM) belum lama ini. Sehingga dr. Dwi Handono menilai, salah satu cara memperbaiki minimnya minat dokter muda mengabdi di daerah terpencil adalah dengan memperbaiki kurikulum. Menurutnya, perlu ada tambahan kurikulum berbasis lokal dan wawasan Nusantara mengingat wilayah Indonesia yang sangat luas, termasuk daerah terpencil (Rifa Nadia Nurfuadah, "Sarjana Kedokteran Enggan Mengabdi di Daerah Terpencil", http://news.okezone.com/amp/2015/03/30/65/1126446/sarjana-kedokteran-engganmengabdi-di-daerah-terpencil, diakses 15 Februari 2016).

Dalam profesi dokter ada tiga aturan dasar yang mengatur ruang lingkup dokter, yaitu: (1) etika kedokteran; (2) disiplin ilmu kedokteran; dan (3) hukum (Hukum Pidana, Hukum Perdata, dan Hukum Administrasi). Namun sebelum berbicara tiga aturan tersebut, perlu diketahui bahwa dokter dalam menjalankan profesinya wajib diambil sumpah yang dikenal dengan sumpah kedokteran 
(Hippocartic Oath). Sumpah kedokteran tersebut menjelaskan sebagai berikut (Peraturan Pemerintah Republik Indonesia Nomor 26 Tahun 1960 Tentang Lafal Sumpah Dokter Presiden Republik Indonesia):

"Saya akan membaktikan hidup saya guna kepentingan perikemanusiaan; Saya akan menjalankan tugas saya dengan cara yang terhormat dan bersusila, sesuai dengan martabat pekerjaan saya; Saya akan memelihara dengan sekuat tenaga martabat dan tradisi luhur jabatan kedokteran Saya akan merahasiakan segala sesuatu yang saya ketahui karena pekerjaan saya dan karena keilmuan saya sebagai Dokter; Kesehatan penderita senantiasa akan saya utamakan; Dalam menunaikan kewajiban terhadap penderita saya akan berikhtiar dengan sungguh-sungguh supaya saya tidak terpengaruh oleh pertimbangan Keagamaan, Kebangsaan, Kesukuan, Politik Kepartaian atau Kedudukan Sosial; Saya akan memberikan kepada Guru-guru saya penghormatan dan pernyataan terima kasih yang selayaknya; Teman-sejawat saya akan saya perlakukan sebagai saudara kandung; Saya akan menghormati setiap hidup insani mulai dari saat pembuahan; Sekalipun diancam, saya tidak akan mempergunakan pengetahuan Kedokteran saya untuk sesuatu yang bertentangan dengan hukum perikemanusiaan; Saya ikrarkan sumpah ini dengan sungguh-sungguh dan dengan mempertaruhkan kehormatan diri saya".

Menurut penulis sumpah kedokteran di atas, merupakan kaidah dasar yang memiliki ikatan moral yang mendasari bagi dokter untuk terikat secara moral dan etika, di mana dalam sumpah kedokteran tersebut, dokter diharuskan menggunakan tidak hanya keilmuan secara profesional, namun lebih dari itu harus menggunakan keilmuan untuk kepentingan kemanusiaan dengan penuh hati nurani. Apabila dokter dalam menjalankan profesi kedokteran mampu menghayati dan menjalankan secara utuh isi sumpah kedokteran. Maka dokter tersebut telah menjadikan profesi dokter sebagai profesi mulia (nobile officium).

Telah dijelaskan di atas bahwa dokter memiliki aturan dasar yakni etika kedokteran, disiplin ilmu kedokteran, dan hukum. Etika kedokteran merupakan aturan yang mengatur ruang lingkup dokter terkait dengan perilaku baik terhadap pasien, teman sejawat, dan keluarga pasien, serta menjunjung sumpah kedokteran. Disiplin ilmu kedokteran merupakan aturan yang mengatur ruang lingkup dokter dalam hal menjalankan keilmuan kedokterannya sesuai dengan kebutuhan dan kapasitas dokter tersebut, sebagai contohnya dokter tidak boleh menjalankan tindakan kedokteran terhadap pasien yang bukan keilmuan profesionalnya. Apabila dilanggar, maka tidak hanya etika kedokteran dan sumpah kedokteran saja yang dilanggar, namun juga telah melanggar hukum. Sedangkan hukum merupakan ultimum remidium artinya ketika secara disiplin ilmu kedokteran dokter telah terbukti salah (sengaja atau lalai) menggunakan keilmuannya terhadap pasien, maka hukum melalui institusi negara yang berwenang dapat meminta pertanggungjawaban hukum kepada dokter.

Sementara di sisi lain, menjadi hal penting untuk mengkaji profesi dokter dilihat dari nilai-nilai Pancasila sebagai kaidah dasar negara Indonesia. Ini penting, dikarenakan selama ini secara garis besar pendidikan tentang Pancasila di negara 
ini mulai memudar, dan nilai-nilai Pancasila hanya dijadikan sebagai seremonial belaka ketika memperingati hari Pancasila. Selain itu ketika dokter terkena masalah hukum karena dugaan kesalahan medis dokter (malpraktik dokter), masyarakat, internal dokter, menteri kesehatan, serta penegak hukum hanya sebatas melihat kasus semata, tanpa meneliti lebih jauh apakah dokter Indonesia dalam pendidikan kedokteran telah diberi pendidikan Pancasila, dan telah pula menjiwai nilai-nilai pancasila dalam setiap menjalankan profesi kedokteran. Berangkat dari permasalahan yang telah diuraikan di atas, maka dapat dirumuskan permasalahan dalam kajian ini yakni, apakah dokter dalam menjalankan profesinya telah menjiwai nilai-nilai Pancasila?

\section{B. PEMBAHASAN}

\section{Profesi Dokter}

Sejarah menunjukkan bahwa di Mesir kuno, seperti apa yang ditemukan dalam bentuk tulisan pada dinding piramida, sudah ada pembedahan antara dokter (physician), dan para pemulih kesehatan magis (magician). Imhotep yang hidup kira-kira tahun 3000 SM. dinobatkan sebagai ilāh orang Mesir Kuno. Ia digelari dengan sebutan "The Good Physican of Gods and Men", karena pertolonganpertolongan yang diberikannya kepada mereka yang menderita sakit dan penyakit, menyembuhkan dan memulihkan kesehatan manusia, serta menyediakan peristirahatan yang sempurna bagi mereka yang dilanda tekanan mental dan emosional. Para ahli meracik obat-obatan dan rempah-rempah dalam kitab perjanjian lama (keluaran 30: 25-35) sudah hampir pasti adalah orang-orang yang dididik dan dilatih dalam salah satu kuil yang didirikan untuk memuliakan Imhotep (Tengker, 2005: 5).

Menurut Bernard Barber, profesi mengandung esensi sebagai berikut (Dahlan,2000:18):

a. membutuhkan ilmu pengetahuan yang tinggi yang hanya dapat dipelajari secara sistematik;

b. orientasi primernya lebih ditujukan untuk kepentingan masyarakat;

c. memiliki mekanisme kontrol terhadap perilaku pemegang profesi; dan

d. memiliki sistem reward.

Sementara definisi dokter dan dokter gigi sebagaimana yang termuat dalam Pasal 1 ayat (2) Undang-Undang No.29 Tahun 2004 Tentang Praktek Kedokteran adalah "Dokter, dokter spesialis, dokter gigi, dan dokter gigi spesialis lulusan pendidikan kedokteran atau kedokteran gigi baik di dalam maupun di luar negeri yang diakui oleh Pemerintah Republik Indonesia sesuai dengan peraturan perundangundangan".

Ketika membahas pengertian dokter dan dokter gigi secara keseluruhan seperti yang telah dijelaskan di atas, maka tidak terlepas juga dengan pengertian profesi kedokteran yang menjalankan praktek kedokteran. Dikarenakan pada sisi lain praktek kedokteran bukanlah pekerjaan yang dapat dilakukan oleh siapa saja, melainkan hanya boleh dilakukan oleh kelompok profesional kedokteran tertentu, 
dan telah mendapatkan izin dari institusi yang berwenang, serta bekerja sesuai dengan standar dan profesionalisme yang ditetapkan oleh organisasi profesi (Nusye, 2009: 31).

Suatu tindakan dokter yang profesional disebut legeartis jika tindakan itu dilakukan sesuai dengan standar profesi dokter yang diindikasikan dengan tindakan yang dilakukan secara teliti dan sesuai ukuran medic. Kaitannya dengan hal tersebut dapat dikemukakan melalui jurisprudensi Supreme Court of Canada 1956 yang memberikan komentar tentang Principle of Liability seorang dokter yang terdiri dari lima unsur sebagai berikut (Hatta, 2013: 84):

a. tindakan yang teliti dan hati-hati;

b. sesuai standar medis;

c. sesuai dengan kemampuan dokter menurut ukuran tertentu;

d. dalam situasi dan kondisi yang sama; dan

e. keseimbangan antara keseimbangan tindakan dengan tujuan.

H.J.J. Lenen, mengemukakan bahwa tujuan ilmu kedokteran adalah sebagai berikut (Ameln, 1991):

a. het genezen en vookomen van ziekte. Maknanya adalah menyembuhkan dan mencegah penyakit. Seorang dokter wajib melakukan tindakan medis yang ada gunanya, yaitu tindakan medis yang mengandung kemungkinan untuk menyembuhkan pasien atau memberhentikan proses penyakit, atau mencegah suatu penyakit. Tindakan yang tidak ada gunanya, misalnya dalam memperpanjang proses kematian seorang pasien dapat menimbulkan suatu masalah karena tindakan medis tersebut tidak ditujukan pada tujuan medis.

b. het verzachten van lijden. Maknanya meringankan penderitaan seorang pasien. memperingan penderitaan pasien menjadi tujuan tradisional pengobatan yang merupakan bagian persetujuan terapeutik. Meringankan penderitaan berarti bahwa dokter harus berusaha mencegah sebanyak mungkin adanya penderitaan yang bisa terjadi akibat tindakan medis.

c. het begeleiden van de patient, waaronder begrepen stervens begeleiding. Maknanya membimbing pasien, termasuk dalam hal ini membimbingny dalam mengahadapi akhir hidup.

\section{Etika Kedokteran}

Kamus Besar Bahasa Indonesia mengatakan bahwa etika adalah ilmu tentang apa yang baik dan apa yang buruk, dan tentang hak dan kewajiban (Pusat Bahasa Kementrian Republik Indonesia, 2008: 399). Kaitannya dengan etika menurut Bartens, menjelaskan etika berasal dari bahasa Yunani kuno yaitu ethos dalam bentuk tunggal yang berarti adat kebiasaan, adat istiadat, akhlak yang baik. Bentuk jamak dari ethos adalah ta etha artinya adat kebiasaan. Dari bentuk jamak ini terbentuklah istilah etika yang oleh filusuf Yunani Aristoteles (384-332 SM) sudah dipakai untuk menunjukkan filsafat moral (Supriadi, 2010: 9).

Sedangkan menurut James J. Spillane S.J., yang mengungkapkan bahwa etika atau ethic lebih memperhatikan atau mempertimbangakan tingkah laku manusia 
dalam pengambilan keputusan moral. Etika mengarahkan atau menghubungkan penggunaan akal budi individual dengan objektivitas untuk menentukan "kebenaran" atau "kesalahan" dan tingkah laku seseorang terhadap orang lain. Selain itu dalam istilah latin, ethos atau ethikos selalu disebut dengan mos, sehingga dari perkataan tersebut lahirlah moralitas atau yang sering diistilahkan dengan perkataan moral (Suhrawardi, 1994: 1).

Lebih lanjut bahwa dalam bahasa agama islam, istilah etika ini merupakan bagian dari akhlak. Menjadi bagian dari akhlak bukanlah sekedar menyangkut perilaku manusia yang bersifat perbuatan yang lahiriah saja, akan tetapi mencakup hal-hal yang lebih luas, seperti bidang akidah, ibadah, dan syariah. Dalam Bahasa Indonesia perkataan etika ini kurang begitu populer dan lazimnya istilah ini lebih sering digunakan di kalangan terpelajar. Kata yang sepadan dengan itu serta lazim dipergunakan di tengah-tengah masyarakat adalah perkataan "susila" atau "kesusilaan". Kesusilaan berasal dari bahasa Sansekerta, yaitu terdiri dari kata su dan sila. Kata "su" berarti bagus, indah, cantik. Sedangkan "sila" berarti adab, kelakuan, perbuatan adab (sopan santun dan sebagainya), akhlak, moral. Dengan demikian perkataan "susila" atau kesusilaan dapat berarti adab yang baik, kelakuan yang bagus, sepadan dengan kaidah-kaidah, norma-norma atau peraturanperaturan yang berlaku (Suhrawardi, 1994: 1).

Sejalan dengan ini, apabila dikaitkan dengan Akhlak dalam Islam cakupannya sangatlah luas, yaitu menyangkut etos, etis, moral, dan estetika sebagai berikut (Supriadi, 2010: 9):

a. etos mengatur hubungan seseorang dengan khaliknya, serta kelengkapan ulūhiyah dan rubūbiyah, seperti terhadap rasul-rasul Allah, kitab-kitab-Nya, dan sebagainya;

b. etis mengatur sikap seseorang terhadap dirinya dan terhadap sesama dalam kegiatan kehidupan sehari-harinya;

c. moral mengatur hubungan dengan sesama, namun berlainan jenis dan/atau yang menyangkut kehormatan tiap pribadi.

d. estetika merupakan cabang dari filsafat yang memiliki rasa keindahan yang mendorong seseorang untuk meningkatkan keadaan dirinya serta lingkungannya agar lebih indah dan menuju kesempurnaan.

Beranjak dari pengertian etika dari beberapa pakar tersebut, maka menurut A. Sonny Keraf, etika dipahami dalam pengertian moralitas sehingga mempunyai pengertian yang lebih luas dalam pelaksanaan di manapun itu. Etika dapat dipahami sebagai refleksi kritis tentang bagaimana manusia harus hidup dan bertindak dalam sistem situasi nyata atau situasi khusus tertentu. Etika adalah filsafat moral, atau ilmu yang membahas dan mengkaji secara kritis persoalan benar dan salah secara moral, tentang bagaimana harus bertindak dalam situasi konkret. Dalam perkembangannya, etika dapat dibagi menjadi dua: (1) etika perangai; dan (2) etika moral. Etika perangai adalah adat istiadat atau kebiasaan yang menggambarkan perangai manusia dalam hidup bermasyarakat di daerah tertentu, pada waktu tertentu pula. Etika perangai tersebut diakui dan berlaku karena disepakati 
masyarakat berdasarkan hasil penilaian perilaku seperti, berbusana adat, pergaulan remaja, perkawinan semenda, dan upacara adat (Supriadi, 2010: 8). Sebagai cabang filsafat, etika membahas tentang moralitas manusia. Dalam beberapa buku, etika diartikan sebagai filsafat tingkah laku (perilaku), sedangkan dalam buku-buku yang lain disebut sebagai filsafat moral (Podejawijatna,1990: 12).

Sejak semula etika profesi kedokteran dilandaskan pada asas-asas etika umum yang mengatur hubungan manusia pada umumnya. Maksudnya, masyarakat berwenang menilai dan mengoreksi apabila etika tersebut tidak ditaati. Keluhan masyarakat yang pada akhir-akhir ini timbul, hendaknya diterima sebagai masukan yang konstruktif dalam rangka mengembangkan kode etik kedokteran itu sendiri. Kalaupun arti, fungsi, isi, dan bentuk dari kode etik kedokteran dipahami, dimengerti oleh para dokter, maka baginya wajib secara moral untuk mengamalkan sesuai dengan tujuan dibentuknya kode etik tersebut (Astuti, 2009: 39).

Dasar etika profesi kedokteran, dapat dijabarkan menjadi enam asas etika yang bersifat universal, yang juga tidak akan berubah dalam etika profesi kedokteran, yaitu (Yunanto, 2010: 8-9):

\section{a. Asas menghormati otonomi pasien (Principle of Respect to The Patient's Autonomy)}

pasien mempunyai kebebasan untuk mengetahui apa yang akan dilakukan oleh dokter serta memutuskan apa yang terbaik bagi dirinya sendiri, sehingga kepadanya perlu diberikan informasi yang cukup. Pasien berhak untuk menghormati pendapat dan keputusannya, dan tidak boleh dipaksa. Oleh karenanya perlu adanya informed consent.

\section{b. Asas Kejujuran (Principle of Vercity)}

Dokter hendaknya mengatakan hal yang sebenarnya secara jujur akan apa yang terjadi, apa yang dilakukan, serta akibat/risiko yang dapat terjadi. informasi yang diberikan hendaknya disesuaikan dengan tingkat pendidikan pasien. Selain jujur kepada pasien, dokter juga harus jujur kepada diri sendiri.

\section{c. Asas tidak merugikan (principle of non-malefience)}

Dokter berpedoman primum non nocere, tidak melakukan tindakan yang tidak perlu, dan mengutamakan tindakan yang tidak merugikan pasien, serta mengupayakan resiko fisik, resiko psikologis, maupun resiko sosial akibat tindakan tersebut seminimal mungkin.

\section{d. Asas manfaat (princple of benefience)}

Semua tindakan dokter yang dilakukan terhadap pasien harus bermanfaat bagi pasien guna mengurangi penderitaan atau memperpanjang hidupnya. Dokter wajib membuat rencana perawatan yang berlandaskan pada pengetahuan yang sahih dan dapat berlaku secara umum. Kesejahteraan pasien perlu mendapat perhatian yang utama. Resiko yang mungkin timbul dikurangi sampai seminimal mungkin sementara manfaatnya harus semaksimal mungkin bagi pasien. 


\section{e. Asas Kerahasiaan (principle of confidentality)}

Dokter harus menghormati rahasia pasien, meskipun pasien tersebut sudah meninggal dunia.

\section{f. Asas Keadilan (principle of justice)}

Dokter harus berlaku adil, tidak memandang kedudukan atau kepangkatan, tidak memandang kekayaan, dan tidak berat sebelah dalam merawat pasien.

\section{Hubungan Hukum Dokter dan Pasien}

Hubungan pasien dan dokter dalam upaya penyembuhan dipahami tidak lagi sekedar hanya pengobatan pada umumnya, tetapi dipahami sebagai hubungan terapeutik (kontraktual). Pasien diwajibkan memahami hak dan kewajiban dalam setiap upaya penyembuhan kesehatannya oleh dokter. Upaya ini harus diperoleh dari kerja sama antara pasien dengan dokter, dikarenakan dalam perjanjian terapeutik kedudukan antara pasien dan dokter adalah sejajar, terkait dengan semua upaya tindakan medis yang dilakukan oleh dokter, demi kesembuhan pasien dari penyakit (Hasrul Buamona, "Kajian Yuridis Tentang Rekam Medis", http://www.lbhyogyakarta.org/2013/05/kajian-yuridis-tentang-rekam-medis/, diakses 24 Mei 2013).

Menurut penulis, hubungan hukum adalah hubungan antara sesama manusia, badan hukum dengan manusia, serta badan hukum dangan badan hukum lain, sebagai subjek hukum yang terikat oleh suatu hubungan kontraktual (terapeutik) maupun undang-undang secara luas, yang telah disepakati sehingga menimbulkan hak dan kewajiban dari hubungan hukum tersebut. Apabila dikaitkan hubungan antara pasien dan dokter atau dokter gigi merupakan suatu hubungan yang lebih mengarah kepada pelayanan kesehatan atau yang sering dikenal dalam dunia medis sebagai health provider dan health receiver. Perjanjian atau biasanya disebut dengan hubungan terapeutik merupakan hubungan timbal balik yang terjadi antara dokter dan pasien yang menghasilkan kesepakatan melalui persetujuan tindakan kedokteran (informed consent). Perjanjian terapeutik ini merupakan hal khusus yang terdapat dalam dunia medis, dikarenakan objek dari perjanjian tersebut merupakan upaya penyembuhan kesehatan. Terkait perjajian terapeutik turut diatur dalam Pasal 1233 KUHPerdata yang menyatakan bahwa "tiap-tiap perikatan dapat dilahirkan dari suatu perjanjian maupun karena undang-undang". Terkait pasal ini, apabila hanya dilihat pada suatu perjanjian, maka akan lebih cenderung pada aspek hukum perdata terkait wanprestasinya dokter atau pasien dalam hubungan terapeutik. Namun apabila dilihat dalam konteks karena undang-undang, kepatutan, dan kepentingan perlindungan kesehatan pasien yang menjadi tanggung jawab negara, maka aspek hukum baik perdata dan pidana bisa masuk untuk meminta pertanggung jawaban hukum kepada dokter maupun pasien yang lalai dalam menjalankan hubungan terapeutik karena telah terjadi perbuatan melawan hukum.

Ketika hubungan dokter dan pasien disertai dengan permintaan dokter untuk mendapatkan imbalan jasa dari klien (pasien) dan klien (pasien) bersedia memenuhinya maka terjadilah hubungan yang disebut sebagai hubungan 
kontaraktual. Pada hubungan kontraktual terdapat kewajiban dan hak dari kedua belah pihak yang harus dihormati serta tanggung jawab jika ada yang tidak memenuhi kesepakatan tersebut. Karena sifat hubungan yang tidak seimbang tersebut maka faktor kepercayaan memegang peran penting. Pasien hendaknya bersikap jujur atas upaya yang akan dilakukan dokter untuk menolong pasien. Selain itu dokter juga harus dapat dipercaya bahwa ia akan menyimpan rahasia pasien serta tidak akan mengungkapkan rahasia itu kepada siapapun tanpa persetujuan pasien kecuali atas perintah undang-undang. Saling percaya dan saling dapat dipercaya ini sangat penting dalam menjaga hubungan yang akan memungkinkan dokter mencari penyelesaian bagi keluhan pasiennya (Yunanto, 2010: 13).

Berdasarkan hubungan tersebut terlihat superioritas dokter terhadap pasien dalam bidang ilmu biomedis. Hanya dokter yang aktif sedangkan pasien bersifat pasif. Hubungan ini berlangsung berat sebelah dan tidak sempurna karena merupakan pelaksanaan wewenang oleh yang satu terhadap yang lain. Oleh karena hubungan dokter-pasien merupakan hubungan antar manusia, maka lebih dikehendaki hubungan yang mendekati persamaan hak antar keduanya adalah kewajiban kedua belah pihak untuk menciptakan kemitraan untuk saling terbuka (Yunanto, 2010: 14).

Sebenarnya pola dasar hubungan dokter dan pasien, terutama berdasarkan keadaan sosial budaya dan penyakit pasien, menurut Szas dan Hollender (1956), dapat dibedakan menjadi tiga, yaitu (Maramis dan Daeng, 2005: 21):

\section{a. Activity-Passivity}

Pola hubungan ini terjadi pada pasien yang keselamatan jiwanya terancam atau sedang tidak sadar, atau menderita gangguan mental berat. Pola terapi terjadi dalam keadaan pasien tidak berdaya.

\section{b. Guidance-Cooperation}

Hubungan membimbing kerjasama, seperti halnya hubungan antara orang tua dengan remaja. Pola ini terjadi bila keadaan penyakit pasien tidak terlalu berat, misalnya penyakit infeksi baru atau penyakit akut lainnya. Meskipun sakit, pasien tetap sadar dan memiliki perasaan serta kemauan sendiri. Ia berusaha mencari pertolongan pengobatan dan bersedia bekerja sama. Walaupun dokter mengetahui lebih banyak, ia tidak semata-mata menjalankan wewenangnya, namun mengharapkan kerja sama pasien yang diwujudkan dengan menuruti nasihat dan anjuran dokter.

\section{c. Mutual Participation}

Filosofi dasar dari pola pendekatan ini adalah berdasarkan pemikiran bahwa setiap manusia memiliki martabat dan hak yang sama. Pola ini terjadi pada mereka yang ingin memelihara kesehatan dengan melakukan medical check up atau pada pasien yang menderita penyakit kronis seperti hipertensi atau diabetes melitus. Pasien secara sadar dan aktif berperan dalam pengobatan terhadap dirinya sendiri. 


\section{Nilai-Nilai Pancasila}

Mengungkap kembali Pancasila sebagai ideologi bangsa yang bersifat terbuka, flexibel, dan dinamis seiring dengan era reformasi yang terjadi sekarang ini, merupakan isu yang sangat relevan. Kenyataan menunjukkan betapa derap reformasi yang terjadi terkesan melupakan dan bahkan meninggalkan Pancasila yang menjadi way of life, sehingga reformasi berjalan tanpa kendali, lupa pada jati diri bangsa yang telah disepakati oleh bangsa Indonesia sejak berdirinya (Mansyur, 2012: 274).

Penekanan orientasi pada manusia sebagaimana nilai-nilai yang terkandung dalam sila Pancasila, menurut Magnis Suseno mencakup 5 (lima) hal sebagai berikut (Mansyur, 2012: 283-284):

a. Pembangunan hukum hanya dapat dipertahankan apabila dilandasi oleh sikap hormat terhadap manusia, mengakui kedudukan manusia yang sama, tidak memperlakukan manusia sebagai objek perencanaan, tidak pernah mengorbankan pihak yang satu demi keuntungan pihak lain dan tidak membeli kemajuan dengan menyengsarakan orang lain. Pengejawantahan sikap ini sesuai dengan sila ke-2 Pancasila, "Kemanusiaan yang adil dan beradab".

b. Pembangunan hukum tidak menjadikan manusia sebagai objek sasaran atau bahkan sarana dan korban bagi usaha kemajuan. Maka, hendaknya pembangunan tidak dilaksanakan secara paternalistik dan teknokratis, melainkan secara dialogis dan partisipatif. Pengejawantahan sikap ini, sesuai dengan sila ke-5 Pancasila, "Kerakyatan yang dipimpin oleh hikmah kebijaksanaan dalam permusyawaratan perwakilan".

c. Menghormati martabat manusia secara konkrit yang berarti menjamin segi-segi asasi manusia. Pengejawantahan sikap ini sesuai dengan sila ke-2 dan ke-4 Pancasila.

d. Mengoperasikan prinsip-prinsip hormat terhadap martabat manusia ke dalam struktur dan lembaga kehidupan masyarakat. Pengejawantahan sikap ini sesuai dengan sila ke-5, "Keadilan bagi seluruh rakyat Indonesia".

e. Sikap hormat terhadap martabat manusia bagi suatu pembangunan perlu dikemukakan tuntutan normatif terhadap penentuan prioritas pembangunan. Pengejawantahan ini sesuai dengan sila ke-2 dan ke-3.

Objek filsafat Pancasila ialah seluruh realitas yang dialami oleh manusia, terlepas dari disadari atau tidak oleh manusia. Seluruh realitas itu ingin dipahami dan ingin diketahui oleh filsafat Pancasila. Argumentasi dalam Pancasila harus dapat dipulangkan kembali atau dipertanggungjawabkan kembali kepada postulatpostulat ilmu Pancasila. Postulat tersebut di antaranya sebagai berikut (Wreksosuharjo, 2014: 41):

a. Ontologi Pancasila harus sampai pembahasan mengenai Postulat Ontologis Pancasila, yaitu bahwa Allah itu ada, manusia itu ada, dan benda itu ada. Bagi masyarakat bangsa Indonesia, mengenai persoalan adanya Allah itu 
sebenarnya sudah bukan persoalan lagi. Artinya disertai bukti-bukti ilmiah atau tidak, bagi bangsa Indonesia bahwa Allah itu ada sudah menjadi keyakinannya.

b. Antropologia Metafisika Pancasila, di mana filsafat manusia Pancasila harus menghasilkan pemahaman mengenai hakikat manusia Pancasila yang monopluralis, yang berarti ditemukannya postulat aksiologis Pancasila. Sebagai pemikir kefilsafatan, seorang filusuf mempersoalkan apakah sebenarnya diri kita yang disebut manusia? Filsafat Pancasila berpendapat bahwa manusia itu sungguh-sungguh ada dan itu adalah manusia yang utuh. Apabila manusia itu tidak ada, maka Pancasila pun tidak ada. Namun, harap diingat bahwa Pancasila itu bukan agama. Pancasila adalah filsafat yang merupakan hasil bekerjanya akal budi manusia.

c. Pancasila adalah sumber nilai dan sumber pedoman bagi seluruh rakyat dan bangsa Indonesia dalam menghadapi hidup, melakukan tugas-tugas hidup, menyelesaikan persoalan hidup, dan menempatkan diri dalam sistem kegiatan kehidupan bersama, guna mencapai tujuan hidup kemanusiaan. Ada orang pemeluk suatu agama yang berpendapat "Aku tidak mau melaksanakan Pancasila, kalau Pancasila itu harus dijadikan sumber nilai dan sumber pedoman, karena itu berarti bahwa aku telah melaksanakan sinkretisme agama yang aku peluk dengan Pancasila. Pendapat dan pendirian itu sesungguhnya salah. Sesungguhnya adalah bahwa memang ada pengaruh timbal balik antara agama-agama yang diakui sah di Indonesia dengan Pancasila. Agama-agama di Indonesia mempunyai pengaruh material kepada Pancasila dan Pancasila mempunyai pengaruh formal yuridis dan moral kepada agama-agama di Indonesia.

Cita hukum bangsa Indonesia berakar dalam Pancasila yang oleh para pendiri Negara Republik Indonesia ditetapkan sebagai landasan kefilsfatan dalam menata kerangka dan struktur dasar organisasi negara sebagaimana yang dirumuskan dalam UUD 1945. Pancasila adalah pandangan hidup bangsa Indonesia yang mengungkapkan pandangan bangsa Indonesia tentang hubungan antara manusia dan Tuhan, manusia dan sesama manusia, serta manusia dan alam semesta yang berintikan keyakinan tentang tempat manusia individual di dalam masyarakat dan alam semesta (Sidharta, 2009: 181).

Hal senada juga sama dengan kaidah Adat Se Atoran di bumi Sula Kesultanan Ternate yang memiliki nilai etika dan moral, yang juga memiliki kerterkaitan tidak hanya antar sesama manusia sebagai subjek hukum, melainkan juga dengan alam dan Allah Swt. Esensi dari nilai-nilai Adat Se Atoran tersebut menjelaskan bahwa keberadaan manusia harus dimuliakan. Maka dengan ini, dalam Adat Se Atoran jelas terlihat ada hubungan vertikal manusia dengan Allah Swt, dan hubungan horizontal antara manusia dengan sesama manuisa beserta sesama mahluk hidup lain termasuk alam. Sehingga menjadi patut bahwa nilai-nilai yang luhur ini, harus menjadi dasar kehidupan berbangsa dan bernegara (Hasrul Buamona. Opini Koran Malut Post, 24 Agustus 2016). 
Sebagai sistem nilai, Pancasila merupakan "base-values" dan sekaligus juga merupakan "goal-values" (Sidharta, 2009: 181). Tidak dapat dipungkiri bahwa pada beberapa dekade terakhir, ada kerisauan pada sementara komponen bangsa terhadap arah dan perkembangan politik hukum nasional yang semakin tidak lagi menempatkan Pancasila sebagai sumber pembentukan, pelaksanaan, maupun penegakkannya. Kondisi seperti itu menjadi relevan dipertanyakan, mengapa terjadi inkonsistensi implementasi nilai-nilai Pancasila dalam UUD 1945 dalam politik hukum nasional? Kajian yuridis-sosiologis menunjukkan bahwa faktor utama munculnya permasalahan itu karena bangsa ini agaknya berada dalam kesesatan berpikir tentang hukum (Sudjito, 2016: 6).

Abdul Kadir Besar menyatakan Pancasila tergolong nilai instrinsik, yaitu nilainilai yang menjadi dambaan orang, berkat apa adanya dia, berkat ciri-ciri yang dimilikinya, atau relasi antar ciri. Dengan demikian Pancasila sebagai sistem nilai akan mantap berfungsi sebagai pandangan hidup bangsa (way of life) apabila semua warga negara sebagai komponen bangsa telah meyakini kebenaran nilai-nilai Pancasila. Hasil dari proses perburuan kebenaran hakiki atas tiga hal: manusia, alam, serta Tuhan Yang Maha Esa, akan melahirkan apa yang di dalam ilmu disebut paradigma (Sudjito, 2007: 3).

\section{Pancasila dalam Profesi Dokter}

Profesi dokter dengan nilai-nilai Pancasila memiliki hubungan yang erat. penulis melihat hubungan erat tersebut dipengaruhi oleh profesi kedokteran yang berkedudukan di wilayah negara Indonesia yang menjadikan Pancasila sebagai norma dasar bernegara. Pancasila itu sendiri merupakan nilai universal yang sebenarnya tidak hanya diberlakukan bagi negara Indonesia saja, namun memiliki nilai universal yang bisa digunakan oleh profesi kedokteran yang ada di negara lain. Ini karena Pancasila memiliki nilai transedental yang dapat diaplikasikan dalam moral dan etika yang harus dimiliki oleh dokter untuk memberi pelayanan medis kepada pasien dengan sikap yang penuh hati nurani.

Namun dalam perjalanan profesi dokter pada saat sekarang nilai-nilai Pancasila terasa jauh dan krisis dari segala kegiatan profesi dokter. Pada dasarnya ini tidak hanya terjadi dalam profesi dokter, namun dalam profesi lain seperti advokat. Pendidikan khusus profesi advokat tidak memuat Pancasila sebagai bahan pembelajaran bagi calon advokat. Seharusnya menjadi penting ketika nilai-nilai Pancasila dimasukan dalam pembelajaran profesi dokter pada khususnya, dikarenakan dalam menjalankan profesinya ke depan diwajibkan untuk memberikan pelayanan medis yang penuh hati nurani tanpa membedakan-bedakan, baik dari aspek sosial maupun ekonomi pasien.

Dalam menjalankan profesi dokter, baik secara personal maupuun secara organisasi, tidak bisa melepaskan nilai-nilai Pancasila. Ini karena nilai-nilai Pancasila memiliki kaitan dan pertanggungjawaban secara transedental kepada Allah Swt, serta dengan manusia itu sendiri sebagai wujud dari kemanusiaan yang adil dan beradab, atau dalam Islam dikenal dengan rạmmatan lil 'ālamīn, artinya keadiran manusia di muka bumi harus memberi manfaat bagi orang lain. Menurut 
penulis, Pancasila yang merupakan nilai-nilai dasar bernegara harus dibangunkan kembali dari tidur yang panjang. Pancasila pada Orde Baru hanya dimanfaatkan oleh kekuasaan untuk mengamankan kekuasaan, dan bukan untuk tujuan membangun negara dan masyarakat dengan nilai-nilai Pancasila sebagai pijakan dasar bernegara, sehingga dampaknya sekarang nilai-nilai Pancasila terasa asing khususnya bagi profesi dokter itu sendiri.

Melihat usaha yang telah dilakukan oleh internal profesi dokter sendiri untuk menumbuhkan nilai pengabdian dokter kepada masyarakat belum dirasa cukup dikarenakan keuntungan ekonomi yang dijadikan tujuan utama oleh sebagian besar dokter. Sehingga dengan beragamnya persoalan yang ada, sudah saatnya nilai-nilai Pancasila harus dijadikan sebagai paradigma yang termuat dalam proses pendidikan dokter. Penting kemudian agar Pancasila tidak hanya dijadikan sebagai seremonial belaka dalam setiap memperingati hari lahirnya Pancasila. Pancasila sudah saatnya dijadikan sebagai sebuah paradigma keilmuan yang mendasar dan utama dalam setiap proses pendidikan dokter. Apabila nilai-nilai Pancasila tidak dimuat dalam pendidikan dokter, maka akan berdampak pada jauhnya nilai pengabdian bagi dokter sebagaimana dalam sumpah kedokteran, sehingga berdampak juga pada berkurangnya nilai etika kedokteran sampai pada ketidakmauan dokter yang mengabdi di daerah terpencil di seluruh wilayah negara kesatuan republik Indonesia.

\section{PENUTUP}

\section{Kesimpulan dan Saran}

Sejauh ini terlihat bahwa profesi dokter dalam menjalankan profesinya masih jauh dari nilai Pancasila itu sendiri, terlihat dengan masih banyak dokter yang tidak memiliki keinginan untuk mengabdi penuh hati nurani kepada masyarakat yang kurang mampu khususnya yang berada di daerah terpencil. Dikarenakan motivasi sejak awal, yang hanya ingin mencari keuntungan ekonomi setelah menjadi dokter, dengan alasan biaya pendidikan dokter yang sangat mahal. Hal disebabkan dokter dalam akademiknya hanya berfokus pada teori dan praktik medis, tanpa mempelajari dan menjiwai secara komprehensif nilai-nilai Pancasila yang seharusnya menjadi nilai dasar profesi dokter, selain sumpah kedokteran. Selain itu nilai Pancasila hanya dijadikan sebagai serimonial dan hanya untuk memenuhi syarat formil akademik dokter.

\section{Saran}

Menteri Kesehatan Republik Indonesia serta seluruh dekan fakultas kedokteran dan kedokteran gigi harus menyusun kurikulum pendidikan dokter yang tidak hanya disusun berbasis akademik medis dokter dan berbasis nusantara, namun juga harus ditambahkan ataupun memasukan nilai dasar Pancasila dalam kurikulum pendidikan dokter dalam setiap tingkatan pendidikan dokter (Spesialis, Primer, S2, dan S3). Sehingga di masa mendatang, dokter tidak hanya berwawasan akademik medis dokter dan nusantara saja, namun juga memiliki karakter nilai- 
nilai Pancasila, serta tidak membeda-bedakan, baik dari sisi sosial dan ekonomi, maupun kewilayahan dalam memberikan pelayanan medis kepada pasien.

\section{DAFTAR PUSTAKA}

\section{A. BUKU, MAKALAH, DAN JURNAL}

Astuti, Endang Kusuma (2009). Transaksi Terapeutik dalam Upaya Pelayanan Medis Di Rumah Sakit. Jakarta: Citra Aditya Bakti.

Ameln, Fred (1991). Kapita Selekta Hukum Kedokteran. Jakarta: Grafika Tama Jaya. Buamona, Hasrul (2015). Tanggung Jawab Pidana Dokter dalam Kesalahan Medis. Yogyakarta: Parama Publishing.

Dahlan, Sofwan (2000). Hukum Kesehatan.Rambu-Rambu bagi Profesi Dokter. Semarang: BP UNDIP.

Maramis, Willy F. dan Daeng, Handoko (2005). Ethical Aspect in Patient-Doctor Relationship (Biomedical Ethic), (Surabaya, Dutch Foundation For Postgaraduate Medical Courses In Indonesia). Surabaya: Units Airlangga University School Of Medicine.

Hatta, Moh. (2013). Hukum Kesehatan dan Sengketa Medik. Yogyakarta: Liberty.

Nusye, Jayanti K.I. (2009). Penyelesaian Hukum Dalam Malpraktek Kedokteran. Yogyakarta: Pustaka Yustisia.

Suhrawardi, K. Lubis (Tanpa Tahun). Etika Profesi Hukum. Jakarta: Sinar Grafika.

Mansyur, M. Ali (2012). "Pancasila Sebagai Dasar Pengembangan Ilmu Hukum Indonesia". Menggagas Hukum Progresif Indonesia. Yogyakarta: Pustaka Pelajar.

Podejawijatna, I.R. (1990). Etika:Filsafat Tingkah Laku. Jakarta: Rineka Cipta.

Pusat Bahasa Kementrian Republik Indonesia (2008). Kamus Besar Bahasa Indonesia. Jakarta: Kemendiknas Press.

Sidharta, B. Arief (2009). Refleksi Tentang Struktur Ilmu Hukum (sebuah penelitian tentang fundasi kefilsafatn dan sifat keilmuan Ilmu Hukum sebagai landasan pengembangan Ilmu Hukum Nasional Indonesia). Bandung: CV. Mandar Maju.

Shidarta (2009). Moralitas Profesi Hukum. Bandung: Refika Aditama.

Suseno, Frans Magnis (1991). Etika Dasar: Masalah-masalah Pokok Filsafat Moral. Yogyakarta: Kanisius.

Supriadi (2010). Etik dan Tanggung Jawab Profesi Hukum Di Indonesia. Jakarta: Sinar Grafika. 


\section{NOVEELTYY}

Sudjito (2016). "Pancasila Sebagai Dasar Filsafat dan Paradigma Ilmu Hukum". Makalah Program Doktor Ilmu Hukum UII. Yogyakarta.

Tengker, Fredy (2007). Hak Pasien. Bandung: CV Mandar Maju.

Yunanto, Ari (2010). Hukum Pidana Malpraktik Medik. Yogyakarta: Penerbit ANDI. Wreksosuharjo, Sunarjo (2014). Berfilsafat Menuju Ilmu Filsafat Pancasila. Yogyakarta: Penerbit ANDI.

\section{B. PERATURAN PERUNDANG-UNDANGAN}

Peraturan Pemerintah Republik Indonesia Nomor 26 Tahun 1960 Tentang Lafal Sumpah Dokter Presiden Republik Indonesia.

Kitab Undang-Undang Hukum Perdata.

\section{MEDIA CETAK}

Koran Malut Post 24 Agustus 2016.

\section{INTERNET}

http://www.lbhyogyakarta.org/2013/05/kajian-yuridis-tentang-rekam-medis/ http://news.okezone.com/amp/2015/03/30/65/1126446/sarjana-kedokteranenggan-mengabdi-di-daerah-terpencil 